\title{
ÚJ „KAPCSOLATOK”: \\ A ZENETANÁROK, A HITTANÁROK ÉS AZ SNI TANULÓK
}

Szerzők:

Pető Ildikó

Debreceni Egyetem

Szerző e-mail címe:

peto.ildiko@arts.unideb.hu
Lektorok:

Fónai Mihály

Debreceni Egyetem

Papp János

Debreceni Egyetem

Papp Sándor

Miskolci Egyetem

Mező Katalin

Debreceni Egyetem

Pető, Ildikó (2017): Új „kapcsolatok”: a zenetanárok, a hittanárok és az SNI tanulók. Különleges Bánásmód, III. évf. 2017/3. szám, 39-53. DOI 10.18458/KB.2017.3.39

\begin{abstract}
Absztrakt
Jelen tanulmány a sajátos nevelési igényü tanulók együttnevelését vizsgálja a pedagógusok két „új” csoportjának az oldaláról. A hittanár-nevelőknek és a zenetanároknak a nevelésben, oktatásban betöltött sajátos helyzetének a felvázolása után egy olyan vizsgálat tapasztalatainak a bemutatása következik, amely arra fókuszál, hogyan látják a saját tudásukat, nehézségeiket, szükségleteiket az együttnevelési helyzetekben. Helyzetük megítéléséhez ún. kontroll csoporthoz viszonyítottuk a vizsgálati eredményeiket. A vizsgálati csoportot a közoktatás klasszikus szereplöi, a közismereti tárgyakat oktató pedagógusok alkották.
\end{abstract}

Kulcsszavak: sajátos nevelési igény, együttnevelés, hitoktatás, zenei nevelés

Diszciplína: pedagógia

\section{Abstract}

This study focuses on the integrated-inclusive education of the students with special educational needs from the side of two 'new' groups of teachers. After outlining the specific situation religious and music teachers perform in education a detailed analysis follows, which focuses on the facts how these people see their own knowledge, difficulties and needs in the inclusive and integrated education. To assess their situation their results are compared to a socalled 'control group'. The study group is formed by the 'classic' actors of public education, the teachers who teach general subjects.

Keywords: inclusion, special educational needs, religious teachers, music teachers

Disciplines: pedagogy 
Napjaink iskoláiban nem csupán tanítóval, tanárral találkozhatunk, mint pedagógussal, hanem olyan új szakemberek is jelen vannak az iskolákban, akik szintén aktívan részt vesznek a nevelés-oktatás folyamatában. Az egyre gyakoribb, hogy a fejlesztőpedagógus, gyógypedagógus, pszichológus mellett a hit- és erkölcstan kötelezővé válásával már ott vannak a hitoktatók is, akik az együttnevelés terjedésével szintén foglalkoznak a sajátos nevelési igényü tanulókkal. Emellett a zeneiskolában dolgozó pedagógusok, illetve hagyományos iskolákban zenét oktató pedagógusok is találkoznak a legkülönbözőbb gyerekekkel a zene kapcsán.

A 2013/14-es tanévtől kezdődően felmenő rendszerben bevezették az erkölcstan, illetve a hittan oktatást, ami miatt erős nyomás van az iskolákon, hogy megfelelően képzett szakemberek lássák el a feladatot. Az állami iskolákban a hittanárok nem az iskola és nem a tantestület tagjai, hanem a megfelelő egyházi jogi személy által alkalmazott szakemberek, akik egyházi felsőoktatási intézményben szereztek hitoktatói, hittanári felsőfokú képesítést és az illetékes egyházi hatóság megbízásával rendelkeznek (Net1, Net2). A képzésük célja, hogy olyan hittanárok kerüljenek az iskolákba, akik megfelelő pedagógiai és pszichológiai ismeretekkel, készségekkel és képességekkel, valamint gyakorlati felkészültséggel rendelkeznek ahhoz, hogy közoktatási és gyülekezeti keretek között hitoktatói munkát végezzenek (Net1, Net2, Net3, Net4).

A zene hatását már évezredekkel ezelőtt is ismerték és célzottan alkalmazták a hétköznapokban és a terápiás gyógyításban. A muzikalitásnak kimutatható kapcsolata van a beszéddel, az olvasással, az írással, sőt a bal agyfélteke és annak funkciói (pl. beszéd és az írás képessége) 10 éves korig hatékonyan fejleszthetőek a zenével, így nagy jelentősége van (lehet) a diszlexia-, diszgráfia prevenciójában is. De a nagy mozgásigényü, vagy az összerendezetlen mozgású, a figyelemproblémákkal küzdő gyerekek fejlesztésében is jó eredményeket lehet elérni a zenével (Reikort 2009, Palatin 2015). A zene segít a konfliktusok megelözésében és a különféle kultúrkörök békés együttélésének a kialakulásában, az éneklés pedig erősíti a koncentráló- és emlékező képességet, továbbá kapcsolatot teremt az értelem és az érzelmek között, jelentősen hozzájárul az általános és a szóbeli kifejezőkészség javulásához (Csébfalvi 1998, Janurik 2008, Dohány 2009). Ráadásul a zenetanítással, a zenével foglalkozó pedagógusok kötetlenebb formában is találkoznak a gyermekekkel, nem csak az iskolai tanórák során, ami a sajátos nevelési igényü gyerekekre igen jó hatással van.

A leghatékonyabb tanárokat jellemző tulajdonságlista jelzi, hogy a jó tanárnak a tárgyi és szakmai tudás mellett olyan emberi kvalitásokkal kell rendelkeznie, amelyek mintaként hatnak a diákokra. A befogadó pedagógustól is elvárt az általános felkészültség, de emellett alapvetö, hogy elfogadó, empatikus, de ugyanakkor reális követelményeket állító személyisége legyen, fontos a nyitottsága, amely a sérült gyermekkel foglalkozó szakemberekkel való együttmüködés alapja (Réthy 2013). „Az integráló pedagógusnak új készségeket kell elsajátítania ahhoz, hogy „mediátorként” tudjon közreműködni a csoport/osztály ép és sajátos nevelési igényü gyermekei között, de fokozottan igaz ez a szülőkkel való kapcsolattartásban is.”(Hernádi 2008:27-28) Ez utóbbi igen lényeges, hiszen az SNI tanulók szüleivel való kapcsolatnak együttmüködéssé kell fejlődnie. Általában igaz, hogy minden pedagógus személyisége, attitüdje, a mutatott modell mintaként funkcionál, ami egy együttnevelő közegben további elemekkel gazdagodhat az újfajta közegnek köszönhetően.

A fiatalabb pedagógusok korosztályának többsége elfogadja, illetve megnyerhető a megváltozott feladatú, megújuló pedagógusszerepre, de a szándék és a nyitottság kevés, ha a pedagógiai-szakmai felkészülés során a leendő pedagógusok nem találkoznak a gyakorlatban különböző nevelési-oktatási helyzetekkel, így együttneveléssel, illetve azok megoldási 
lehetőségeivel sem. Konkrét technikai és módszertani eljárások, folyamatleírások helyett csak alapelveket, célokat és követelményeket kapnak. A gyakorlatban gyakran csak a pedagógus ügyességén, rátermettségén, problémamegoldó képességén, kreativitásán, majd pedig a rutinján múlik, hogy milyen módon oldja meg az adódó szituációkat.

\section{VIZSGÁLAT}

A vizsgálat az együttnevelés oldaláról a zenetanárok és hittanár-nevelök (továbbiakban: hittanár) szakmai énképére fókuszál, mivel a hagyományos pedagógusokhoz képest ennek a két csoportnak 15-20 éves lemaradása van az iskolai értelemben formális oktatásban, ezen belül is az SNI gyerekekkel való találkozásban. A vizsgálat célja az volt, hogy megvizsgálja ennek a két ,új” pedagóguscsoportnak, a hittanároknak és zenetanároknak az attitüdjét az SNI tanulókkal kapcsolatban. A vizsgálatba bevontuk a klasszikus oktatási feladatokat ellátó közismereti tárgyakat (továbbiakban: egyéb tanárok) oktatókat is, majd velük összehasonlítva próbáltunk képet alkotni arról, hogyan látják a saját tudásukat, nehézségeiket, szükségleteiket az együttnevelt (integráltan vagy inkluzívan nevelt) sajátos nevelési igényű tanulók oktatásával-nevelésével kapcsolatban.

\section{Vizsgálati eszköz és módszer}

Kezdetben a Debreceni Egyetem Neveléstudományok Intézete keretén belül müködő Együttnevelés kutató csoport vizsgálta a pedagógusoknak az együttneveléssel (integrált, inkluzív) kapcsolatos attitüdjét különböző vizsgálati eszközökkel és módszerekkel. Jelen dolgozat alapját egy olyan, általunk használt eszközzel nyert adatbázis adja, amelyet a kutatócsoport állított össze. A vizsgálati személyeknek az eddigi pedagógiai gyakorlatuk, illetve a munkahelyük bemutatása után öt kérdés mentén kellett gondolkodniuk és választ adniuk önmagukról a sajátos nevelési igényü tanulókkal végzett munkájuk alapján. Válaszaik az integrációval, inklúzióval kapcsolatos szakmai énképük megfogalmazását jelentette, az 5 nyitott „kérdésre” szabadon írásban válaszoltak.

A ,kérdések” valójában megkezdett „én-mondatok” voltak:

- A pedagógiai gyakorlatom változását leginkább akadályozó tényezők...

- Amit a változás eredményességéhez én hozzá tudok adni...

- Amit már most tudok...

- Amihez képeznem kell magamat...

- Amiben segítségre van szükségem az oktatási adaptáció során...

Az egyes kérdésekre adott írásos válaszokban a megfogalmazás sorrendjében sorszámoztuk a gondolataikat, azaz mit említett először, másodszor, majd harmadik helyen. Abból indultunk ki, hogy a vizsgálati személy a megkezdett állítást olvasva és azon elgondolkodva egyfajta fontossági sorrendbe állítja a válaszait az írás közben. Ma, a szövegszerkesztők világában a gondolatok sorrendjén könnyü változtatni attól függően, hogy mit tart fontosabbnak, amit a vizsgálat személyei, feltehetően meg is tettek.

A kapott adatbázis feldolgozása során egyik szempontunk az volt, hogy az iskolai értelemben kevésbé formális zeneoktatás, illetve az iskolákban órarendszerüen csak az utóbbi években megjelenő hitoktatás szakemberei hogyan vélekednek önmagukról és a lehetőségeikről a sajátos nevelési igényü tanulókkal kapcsolatban.

Az adatok elemzése során elkülönítve vizsgáltuk a két kiemelt szak (zenetanár és hittanár), valamint az egyéb tanárok első helyen adott válaszait. Majd összevontuk az első három helyen említett válaszokat, elemeztük a három „szak” szerint, illetve összesítve a teljes 200 
fős vizsgálati csoport esetében. Az elemzés során a válaszok darabszámával dolgoztunk, hiszen nem mindenki adott legalább három választ.

Jelen vizsgálat „pilot study” jelleggel készült, így a mintavétel nem tekinthető reprezentatívnak, az alábbiakban leíró statisztikai szinten elemezzük az eredményeket.

\section{A vizsgálati csoport}

A vizsgálati csoport részben a Debreceni Egyetem levelező MA- tanárképzésben részt vevőkből, részben pedig olyan pedagógusokból állt össze, akikkel egyéb képzések során kerültünk kapcsolatba az elmúlt öt évben. Jelen írásban a hittanár-nevelő és zenetanár szakos pedagógusok válaszaira fókuszálunk összehasonlítva az egyéb szakos pedagógusokkal, mint kontroll csoporttal összehasonlítva. A jelenlegi bemutatásba csak azoknak az adatai kerültek be, akik úgy nyilatkoztak, hogy volt vagy van közük sajátos nevelési igényü tanulóhoz a munkájuk során.

Jelen írás alapját adó elemzésbe 100 fő hittanár és zenetanár szakos, és 100 fő valamilyen más, közismereti szakos („egyéb szakos”) pedagógus került. Így a teljes vizsgálati csoport összesen 200 fös lett, akik közül 64-en férfiak és 136-an nők. Szakokra lebontva, a hittanár szakosok száma 52 fö, a zenetanároké 48 fö, akiknek a nemi aránya meglepően kiegyensúlyozott, 26 férfi és 26 nő hittanár, valamint 22 férfi és 26 nő zenetanár válaszait dolgoztuk fel. (1. táblázat)

\section{1.táblázat. A vizsgálati személyek megoszlása szak és nem szerint (fö)(forrás: a szerzö)}

\begin{tabular}{|l|c|c|c|}
\cline { 2 - 3 } \multicolumn{1}{c|}{} & \multicolumn{2}{c|}{ NEM } & \multirow{2}{*}{ Összesen (fó) } \\
\cline { 2 - 3 } \multicolumn{1}{c|}{} & férfi (fö) & nö (fö) & \\
\hline zenetanár & 22 & 26 & 48 \\
\hline hittanár & 26 & 26 & 52 \\
\hline egyéb tanár & 16 & 84 & 100 \\
\hline Összes & 64 & 136 & 200 \\
\hline
\end{tabular}

A megkérdezett pedagógusok életkora széles skálán mozog, a pályakezdőtől a nyugdíj előtt állóig bezárólag. Közülük a legfiatalabb 23 éves, a legidősebb 61 éves, az átlag életkor pedig 45 év. Ennek megfelelően alakul a szakmában eltöltött évek száma, a hittanárok közül 1-10 éve van a pályán 14 fô, 10-20 éve 24 fö, 20 évnél régebben dolgozik 10 fö. Hasonló képet mutatnak a zenetanárok adatai is, 1-10 éve oktat 10 fö, 10-20 éve 30 fö, 20 évnél hosszabb ideje tanít 12 pedagógus. Az egyéb szakos tanárok közül 16 fő 1-10 éve, 64 fö 10-20 éve, míg 20 fö több mint 20 éve van a tanári pályán (1. diagram).

A vizsgálati csoport tagjai az alapfokú és a középfokú oktatás intézményeiben dolgoznak (2. táblázat). A zenetanárok döntően zeneiskolában, általános iskola és alapfokú müvészeti iskolában, zenemüvészeti szakközépiskolában és AMI-ban tanítanak (46 fö), más intézménytípusban (valamilyen szakközépiskolában) csak 2 fö. 
1. diagram A szakmában eltöltött évek (fö)(forrás: a szerzö)

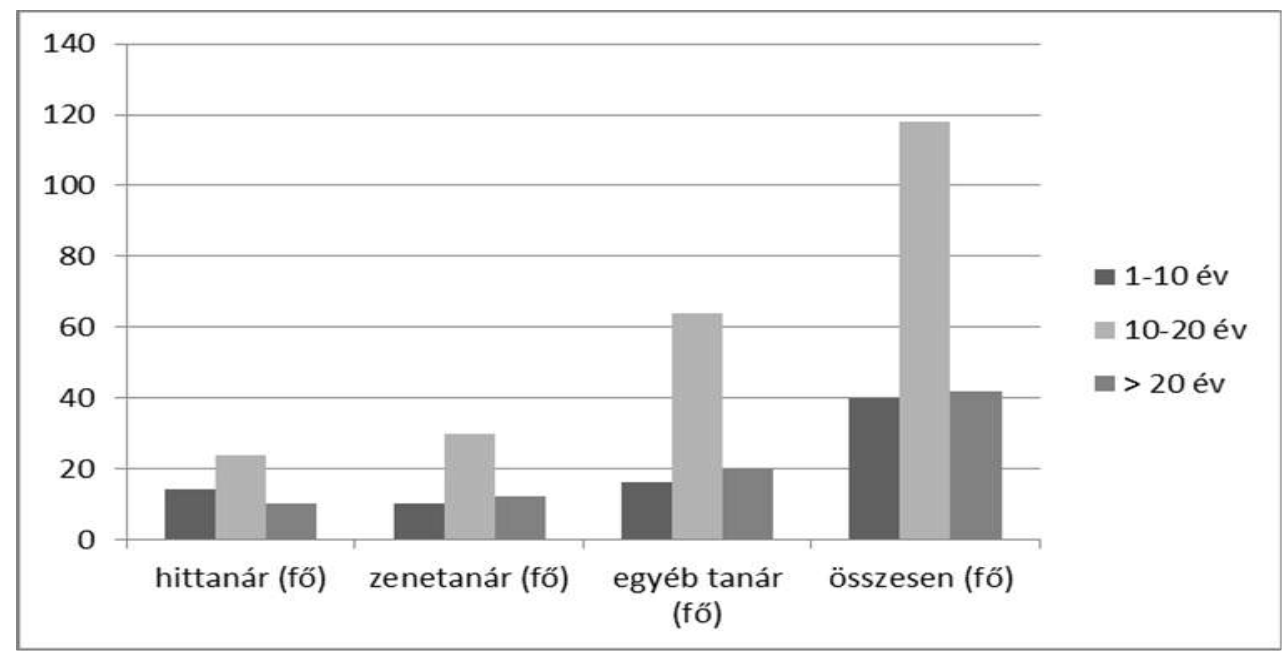

A hittanárok jelentős többsége általános iskolában tanít, az 52 főből csupán 7 fö tanít középfokon (3 fö szakközépiskolában, 4 fö gimnáziumban) (2. táblázat). Közel azonos arányban dolgoznak az egyéb szakos pedagógusok alapfokon (30 fö), és középfokon (32 fó gimnáziumban, 30 fö szakközépiskolában). Csupán csak 8 fö (a 100 főből) áll alkalmazásban a zenetanárok elsődleges terepén, valamilyen müvészeti profilú intézményben.

2.táblázat A vizsgálati személyek megoszlása szak és iskolatípus szerint (fö) (forrás: a szerzö)

\begin{tabular}{|c|c|c|c|c|c|}
\hline & \multicolumn{4}{|c|}{ ISKOLATÍPUS* } & \multirow{2}{*}{ Összesen } \\
\cline { 2 - 5 } & $\begin{array}{c}\text { zenei képzést } \\
\text { folytató intézmény }\end{array}$ & $\begin{array}{c}\text { általános } \\
\text { iskola }\end{array}$ & $\begin{array}{c}\text { szakközép- } \\
\text { iskola }\end{array}$ & gimnázium & \\
\hline zenetanár & 46 & 0 & 2 & 0 & 48 \\
\hline hittanár & 2 & 43 & 3 & 4 & 52 \\
\hline egyéb tanár & 8 & 30 & 30 & 32 & 100 \\
\hline összesen & 56 & 73 & 35 & 36 & 200 \\
\hline
\end{tabular}

*A 200 fö vizsgálati személy munkahelyének az intézménytípusa a jelen írás alapját adó elemzés változói közé nem került be.

Az intézmények földrajzi elhelyezkedése bár kisebb eltolódásokat mutat a településtípusok szerint, de az arányok hasonlóak. Feltünő, hogy a hittanárok kis településen, míg a zenetanárok nagyvárosban dolgoznak jellemzően. (3. táblázat)

3.táblázat A vizsgálati személyek szakja és munkahelyük földrajzi elhelyezkedése (fö) (forrás: a szerzö)

\begin{tabular}{|c|c|c|c|c|c|}
\cline { 2 - 5 } \multicolumn{1}{c|}{} & \multicolumn{4}{c|}{ FÖLDRAJZI HELY } & \multirow{2}{*}{ Összesen } \\
\cline { 2 - 5 } \multicolumn{1}{c|}{} & $\begin{array}{c}\text { falusi- } \\
\text { községi }\end{array}$ & kisváros & nagyváros & fóváros & \\
\hline zenetanár & 0 & 18 & 30 & 10 & 48 \\
\hline hittanár & 20 & 22 & 10 & 0 & 52 \\
\hline egyéb tanár & 10 & 55 & 26 & 9 & 100 \\
\hline összesen & 30 & 85 & 66 & 19 & 200 \\
\hline
\end{tabular}


A válaszokban leírás vagy indoklás is történt, miszerint a vidéki iskolák többsége szerény anyagiakkal rendelkezik, ezért nagyon sokat pályáznak, gyakran sikeresen. A vizsgálati személyek által megadott számadatok szerint az iskolák tanulói létszáma nagyon változó, 90 főtől 1100 főig terjed, és ennek megfelelően alakul a pedagógus létszám és a szaktanári ellátottság is.

A vizsgálati személyek az addigi pedagógiai gyakorlatukat jellemezték néhány mondatban. A zeneiskolában dolgozó zenetanárok abban látják elönyüket az iskolákban dolgozó többi szaktanárral szemben, hogy egyénileg foglalkoznak a tanulókkal, mindenkivel a saját életkorának, képességeinek megfelelően, személyre szabottan. Az adott növendékre koncentrálnak, és nem kell elaprózni a figyelmüket, ezáltal kialakulhat egy bensőséges tanárdiák viszony.

A hittanárok is speciálisnak látják feladatukat a világi tanárokkal szemben, mivel ök nem egy intézményhez kötődnek, hanem egyszerre több iskolában, sőt iskolán kívül is oktatnak, így nem jön létre szoros munkakapcsolat az iskola pedagógusaival. Fontosnak tartják, hogy (a kötelező tananyagon túl) olyan légkör alakuljon ki, amiben a gyerek biztonságban tudja magát, érzi a szeretetet, a megértést, a törődést.

A vizsgálat során csak azoknak az adatai kerültek feldolgozásra, akiknek a pályájuk során már volt tapasztalatuk SNI tanulók oktatásában. Mindannyian úgy vélték, hogy alapvetően hatékonyan tudnak velük foglalkozni, aminek az indokát a zenetanárok és a hittanárok az egyéni bánásmódban és a toleranciában látják.

\section{Vizsgálati eredmények és tapasztalatok}

- „A pedagógiai gyakorlatom változását leginkább akadályozó tényezők ...”

A vizsgálatban résztvevő hallgatóknak arra a kérdésre kellett választ adni, hogy munkájuk során mi jelent számukra akadályt, nehézséget akkor, amikor az oktatás folyamatában sajátos nevelési igényü gyerekkel találkoznak. Az általuk felsorolt akadályokat tíz pontban tudtuk összefoglalni:
1. Szülöi érdektelenség
2. Gyerekek közötti nagy különbség (kompetenciakülönbségek)
3. Hiányok: időhiány, pénzhiány, eszközhiány
4. A gyerekek családi háttere
5. Nagy osztálylétszám
6. A tanulási zavarokkal kapcsolatos ismeretek hiánya
7. Viselkedési problémák
8. Túlterhelt pedagógusok elismerés nélkül
9. Nő az SNI tanulók száma
10. A pedagógusok motiválatlansága

A zenetanárok a munkájukat akadályozó jelenségek közül első helyen említik a gyerekek közötti nagy (kompetencia) különbségeket, 48-föből 19-en, elsősorban azok, akik szolfézst tanítanak. Nagy kihívást jelent számukra, hogy egy-egy csoportban különböző korú és képességü gyerekek vannak, főleg ha még a csoportlétszám is nagy. Ez általában a szolfézs előkészítő, első és második évfolyamán jellemző, amikor az első osztályostól a harmadikos tanulóig osztják be a gyerekeket ugyanabba a csoportba. Az idő-, a pénz-, és az eszközhiányt 48-főből 15 fő jelölte meg, akiknek a válaszaikból kitünik, hogy kevésnek érzik a heti kétszeri 30 perces zenetanítást ahhoz, hogy a növendékük jól fel tudjon készülni egy-egy fellépésre, vagy csak haladjanak a tananyaggal, föleg ha a család nem biztosítja a folyamatos gyakorlást. Sok intézménynek jelent gondot, hogy a színvonalas oktatáshoz szükséges hangszerek számát 
és állapotát biztosítsák, pl. hogy a szükséges kották a rendelkezésükre álljanak. Ilyen esetben, teszik hozzá, nem tehet mást a pedagógus, minthogy saját költségén megveszi, vagy a sajátját adja oda a gyereknek (pl. kották, húrok, hangolást). De kevés pénz jut (ha jut) a versenyekre való jelentkezésre, az utazásra, a verseny alatti ellátás költségeire is. A problémához szorosan kapcsolódik a családi háttér, a szülők érdektelensége, mint ok. Feltételezhetően úgy érzik a zenetanárok (14 fö a 48 föből), hogy a gyakorlás hiánya miatt a gyerekek között egyre nagyobb különbség alakul ki, amiben a szülök felelőssége elvitathatatlan. A zenetanárok az oktatáshoz szükséges anyagiak biztosítását csak az intézménytöl várják el, a család szociális, esetenként szükösebb anyagi lehetőségei nem okoz számukra gondot (0 fö). (4. táblázat).

4. táblázat. A vizsgálati személyek szakja és az „,akadályozó tényezök” (forrás: a szerzö).

\begin{tabular}{|c|c|c|c|c|c|c|c|c|}
\hline \multirow[b]{2}{*}{$\begin{array}{c}\text { „A VÁLTOZÁSOM } \\
\text { AKADÁLYA” }\end{array}$} & \multicolumn{5}{|c|}{ az 1. helyen választott (fö) } & \multicolumn{3}{|c|}{$\begin{array}{l}\text { az 1., a } 2 . \text { és a } 3 . \\
\text { helyen választott }(d b)\end{array}$} \\
\hline & $\begin{array}{l}\text { zene- } \\
\text { tanár }\end{array}$ & $\begin{array}{l}\text { hit- } \\
\text { tanár }\end{array}$ & $\begin{array}{l}\text { zene- } \\
\text { tanár és } \\
\text { hittanár } \\
\text { együtt }\end{array}$ & $\begin{array}{l}\text { egyéb } \\
\text { tanár }\end{array}$ & össz & $\begin{array}{r}\text { zene- } \\
\text { tanár és } \\
\text { hittanár } \\
\text { együtt }\end{array}$ & $\begin{array}{l}\text { egyéb } \\
\text { tanár }\end{array}$ & össz \\
\hline Szülői érdektelenség & 14 & 23 & 37 & 23 & 60 & 44 & 29 & 73 \\
\hline $\begin{array}{l}\text { Gyerekek közötti nagy } \\
\text { különbség (képességek) }\end{array}$ & 19 & 17 & 36 & 32 & 68 & 36 & 35 & 71 \\
\hline Idő-, pénz-, eszközhiány & 15 & 6 & 21 & 18 & 39 & 21 & 21 & 42 \\
\hline A gyerekek családi háttere & 0 & 0 & 0 & 9 & 9 & 57 & 39 & 96 \\
\hline Nagy osztálylétszám & 0 & 0 & 0 & 0 & 0 & 25 & 22 & 47 \\
\hline $\begin{array}{l}\text { Ismeretek hiánya a tanulási zavarokról } \\
\text { (pedagógus részéröl) }\end{array}$ & 0 & 6 & 6 & 18 & 24 & 15 & 40 & 55 \\
\hline Viselkedési problémák & 0 & 0 & 0 & 0 & 0 & 48 & 57 & 105 \\
\hline Túlterhelt pedagógusok (nincs elismertség) & 0 & 0 & 0 & 0 & 0 & 15 & 18 & 33 \\
\hline Nő az SNI tanulók száma & 0 & 0 & 0 & 0 & 0 & 46 & 41 & 87 \\
\hline Motiváció hiánya (pedagógus részéről) & 0 & 0 & 0 & 0 & 0 & 0 & 0 & 0 \\
\hline & & & & Összese & $(\mathrm{db})$ & 307 & 302 & 609 \\
\hline
\end{tabular}

A hittanárok első helyen említik a szülői érdektelenséget, a megkérdezettek majdnem fele (52 föből 23 fö) véli ezt akadálynak, amit azzal magyaráznak, hogy a hittan szabadon választható tantárgy, ezért a szülők is kevesebb figyelmet szentelnek neki, nem biztosítják a szükséges felszerelést, nem kísérik figyelemmel a gyermekük tanulmányi előmenetelét. Szülői érdektelenségnek tekintik a családok megengedő nevelését is, ezért a gyerek alig-alig motiválhatóak. „Az eredményes tanulást akadályozzák azzal a tanulók, hogy érdektelenül állnak a tantárgyamhoz. "(hittanár, nő, 27 éves). Szintén problémát jelent a tanulók fejlettsége közötti különbség (17 fö), mivel a hittanórákon több évfolyamból is vannak tanulók, ami komoly nehézséget jelent, hogy minden gyerek számára az életkorának és az ismereteinek megfelelően folyjék az oktatás. „A csoportok nem egy korosztályból tevödnek össze (1.o.7.o.), más-más tudással és képességgel. A csoportok létszáma is nagyon változó. "(hittanár, férfi, 39 éves). Jelentősen kevesebben, 6-6 fő akadálynak érzi az idő-, pénz- és eszközhiányt, valamint a tanulási zavarral kapcsolatos ismerethiányt. (4. táblázat)

A zene- és a hittanárok választásait összevontuk és összehasonlítottuk az egyéb szakos csoportéval. Az első két ok azonos, de a választások számában tapasztalt különbségek sem meghatározóak. Azonban érdemes észrevenni, hogy a gyerekek családi (szociális és kulturális) háttere az „egyéb” szakosok esetében, ugyan mint kisebb gond, de mégis csak megjelent (100 főböl 9 fö), illetve közel minden ötödik személy megemlítette a saját hiányos ismereteiket a tanulási zavarról (4. táblázat).

Figyelemfelkeltő, hogy az első helyen csak néhány okot választottak szaktól függetlenül a pedagógusok, miközben az első három helyen felsorolt okok összesítését megnézve, nagyon színes képet kapunk, és a sorrend is megváltozik. Mind a zenetanárok és hittanárok, mind az 
egyéb tanárok esetében vezető okká lép elő a család szociális helyzete, a viselkedési problémák és a SNI tanulók számának a növekedése. A két csoport esetében a viselkedési problémák azok, amelyekről úgy érzik, hogy leginkább zavarják és akadályozzák a hatékony munkában (4. táblázat).

Az egyetlen ok, amely magukat a pedagógusokat, a szakmai motiváltságukat nevezi meg, az első három helyen választott okok között egyáltalán nem szerepel egyik csoportban sem (összesen 200 fő közül), ami mindenképpen elgondolkodtató (4. táblázat).

\section{- „Amit a változás eredményességéhez én hozzá tudok adni....”}

A vizsgálatban résztvevő személyeknek azt kellett kifejteniük, hogy mit tudnak hozzáadni a munkájukhoz, hogy azt a legeredményesebben tudják végezni akkor is, amikor SNI tanítványuk van. Véleményük nyolc gondolatkörbe volt besorolható:

1. Differenciált óravezetés (kidolgozott óravázlat)

2. Szemléltető eszközök használata (motiválás)

3. Szülőkkel való kapcsolattartás, családlátogatás

4. Továbbképzéseken való részvétel, új módszerek megismerése

5. Személyes kapcsolat kialakítása a tanulókkal

6. Kapcsolattartás szakemberrel

7. SNI gyerekek speciális igényeinek figyelembe vétele

8. Türelem, kitartás, segítőkészség

A zenetanárok (48 fö) az első választás során szinte hasonló arányban első helyen említették a szülőkkel való kapcsolattartást (13 fö) és a szemléltető eszközök motivációs célú használatát (12 fö). Nem gondolhatjuk, hogy a zenetanítás során olyan mértékben nem szempont az SNI, hogy érthető legyen, hogy 48 föből miért csak 3 fö említette az tanulók speciális igényeit. (5. táblázat)

A hittanárok szintén elsőként említették a szülőkkel való kapcsolattartást (52 főből 20 fö), mint egy olyan pedagógiai eszközt, ami segíti a munkájukat, és már ők maguk is alkalmazzák. De ugyanilyen fontos saját eszközüknek tartják a differenciált óravezetést (20 fö), hogy a differenciálást szolgáló óravázlatokkal készülnek az óráikra. Más, még (első helyen) felsorolt ok csak elhanyagolható számú esetben történt (2-6 fö). (5. táblázat). Azonban elgondolkodtató, hogy a hittanárok nem sorolták fel saját lehetőségeik között a kapcsolattartást a szakemberekkel, a tanítványaik speciális igényeinek a figyelembevételét és a türelmet, kitartást, segítőkészséget, csak negyedik vagy még későbbi helyen. „Személyes elkötelezettségemet, lelkesedésemet, jókedvemet és a türelmemet tudom felajánlani. "(lelkész, férfi, 41 éves). Miközben a nehéz időszakokon túllendítő hatékony és sikert adó munkához elkerülhetetlen az SNI tanulók igényeinek a figyelembevétele, és az, hogy legyenek olyan szakemberek, akikre támaszkodni lehet, akik segítséget tudnak nyújtani, akár a tanulóknak, akár a nevelőknek. A cél közös, mert ha egy tanuló eredményes, a tanár is elégedett a diákkal és önmagával is.

Az egyéb szakos tanároknak az önmagukról vallott, már meglévő lehetőségük szélesebb skálán mozog, és viszonylag egyenletesen oszlanak meg (5. táblázat). A szülőkkel való kapcsolattartás fontosságáról a zene- és a hittanárokhoz hasonlóan vélekednek az egyéb szakosok (16 fó 100 fóből). Viszont a legtöbben (21 fó) a tanulókkal való személyes kapcsolattartásról gondolják azt, hogy már megteszik, a mindennapos pedagógiai gyakorlatuk része. Ha ezt az adatot úgy fordítjuk le, hogy minden ötödik pedagógus törekszik arra, mert 
fontosnak tartja, hogy emberi, tananyagtól és tanulástól mentes, de a tanulás eredményét is befolyásoló kapcsolatot kezdeményezzen és tartson fenn tanítványaival, akkor érdemes lenne megvizsgálni, hogy vajon miért ilyen alacsony ez az arány. Hasonló arányban igyekeznek kapcsolatot tartani a szülőkkel (16 fö) és más szakemberekkel (14 fö), illetve ismereteiket rendszeresen továbbképzésen bővíteni és mélyíteni (16fö).

5. táblázat A vizsgálati személyek szakja és ,,amit már hozzá tudok adni” (forrás: a szerzö)

\begin{tabular}{|c|c|c|c|c|c|c|c|c|}
\hline \multirow[b]{2}{*}{$\begin{array}{c}\text { „MÁR HOZZÁ TUDOK } \\
\text { ADNI” }\end{array}$} & \multicolumn{5}{|c|}{ az 1. helyen választott (fö) } & \multicolumn{3}{|c|}{$\begin{array}{c}\text { az 1., a 2. és a } 3 . \\
\text { helyen választott }(\mathrm{db})\end{array}$} \\
\hline & $\begin{array}{r}\text { zene } \\
\text {-tanár }\end{array}$ & hittanár & $\begin{array}{r}\text { zene- } \\
\text { tanár és } \\
\text { hittanár } \\
\text { együtt }\end{array}$ & $\begin{array}{l}\text { egyéb } \\
\text { tanár }\end{array}$ & össz & $\begin{array}{r}\text { zene- } \\
\text { tanár és } \\
\text { hittanár } \\
\text { együtt }\end{array}$ & $\begin{array}{r}\text { egyéb } \\
\text { tanár }\end{array}$ & össz \\
\hline $\begin{array}{l}\text { Differenciált óravezetés (kidolgozott } \\
\text { óravázlat) }\end{array}$ & 8 & 20 & 28 & 12 & 40 & 28 & 30 & 58 \\
\hline $\begin{array}{l}\text { Szemléltető eszközök használata } \\
\text { (motiválás) }\end{array}$ & 12 & 6 & 18 & 10 & 28 & 27 & 22 & 49 \\
\hline $\begin{array}{l}\text { Szülőkkel kapcsolattartás, } \\
\text { családlátogatás }\end{array}$ & 13 & 20 & 33 & 16 & 49 & 62 & 40 & 102 \\
\hline $\begin{array}{l}\text { Továbbképzésen részvétel, új módszerek } \\
\text { megismerése }\end{array}$ & 4 & 2 & 6 & 16 & 22 & 23 & 32 & 55 \\
\hline Személyes kapcsolat a tanulókkal & 5 & 4 & 9 & 21 & 30 & 49 & 40 & 89 \\
\hline Kapcsolattartás szakemberekkel & 3 & 0 & 3 & 14 & 17 & 16 & 18 & 34 \\
\hline $\begin{array}{l}\text { SNI tanulók igényeinek a figyelembe } \\
\text { vétele }\end{array}$ & 3 & 0 & 3 & 11 & 14 & 25 & 23 & 48 \\
\hline Türelem, kitartás, segítőkészség & 0 & 0 & 0 & 0 & 0 & 16 & 10 & 26 \\
\hline \multicolumn{6}{|c|}{ Összesen $(\mathrm{db})$} & 246 & 215 & 161 \\
\hline
\end{tabular}

A 200 fös teljes vizsgálati csoport összesített adatai szerint az első - második - harmadik helyen megfogalmazott erösségük, amit alkalmaznak a munkájukban, az jellemzően a kapcsolattartás a szülőkkel (102 db), a tanítványaikkal ((89 db) és a differenciált óravezetés (58 db) (5. táblázat). „, Minden tanulóra kiterjedö, az egyéni sajátosságokat figyelembe vevö, és az egyéni képességekhez igazodó tanórai tanulás megszervezése."(zenetanár, nő, 29 éves) „,Olyan légkör kialakitása, ahol érzi a növendékem, hogy mindenben számíthat rám, akár iskolai, akár magánéleti problémai vannak.”(zenetanár, férfi,53 éves) „Csak akkor tudok eredményeket elérni, ha a tanuló érzi, hogy csak vele foglalkozom abban a fél órában, minden energiámat felé forditom és elfogadom az ö véleményét is. "(zenetanár, nő, 38 éves) „Minél jobban megismerjem a diákjaimat, öket mindenféle elöitélet nélkül fogadjam el."(hittanár, férfi, 29 éves).

\section{- Amit már most tudok...}

A megkérdezett pedagógusok „,Amit már most tudok....” gondolatkörben arra adtak választ, hogy az SNI tanulókra fókuszálva már mit tudnak a saját pedagógiai gyakorlatukról, abban mit tartanak fontosnak, milyen szempontokat, jelenségeket fogalmaztak meg maguknak, mint a munkájuk pozitív módosító tényezőjét. A pedagógusok megállapításai, amelyek részben elvként, részben pedig mint társadalmi, iskolai jelenséget fogalmaztak meg, hét kategóriába voltak besorolhatóak:

1. „Fontos a szakmai tudás, tapasztalat”

2. "Nagy segítség a differenciált óravezetés"

3. „Fontos az elfogadó légkör jó példája” 
4. „Szükséges a visszajelzés, fejlesztés (jutalmazás, játék)”

5. „Fontos a személyiségfejlesztés”

6. Egyre több a tanulási zavarral küzdő tanuló”

7. „A gyerekek az otthoni problémát beviszik az iskolába”

A zenetanároknak, akik jellemzően 10-21 éves szakmai tapasztalattal rendelkeznek, az első választása során a leggyakoribb válasz a megfelelő szakmai tudásra és tapasztalatra vonatkozott. (6. táblázat) A válaszadó zenetanárok több mint a felének (26 fó 48 főből) feltételezhetően ez az „elve” a sok éves sikereikből és kudarcaikból fogalmazódott meg. A második legfontosabbnak tartják, (14 fö), hogy jó példát és biztonságot nyújtó légkört biztosítsanak az oktatás-nevelés során. A még két megemlített „elv” egyike az oktatási folyamatra vonatkozik ( 5 fö - segít a differenciált óravezetés), míg a másik a nevelésre (3 fö fontos a személyiségfejlesztés), a választásuk száma elenyésző. (6. táblázat) „ $A z$ egyéni foglalkozások lehetöséget adnak arra, hogy minden növendékemhez, mindegyik személyiségéhez más-más stratégiát dolgozzak ki. ”(zenetanár, férfi, 55 éves).

\begin{tabular}{|c|c|c|c|c|c|c|c|c|}
\hline \multirow[b]{2}{*}{$\begin{array}{l}\text { „MÁR MOST } \\
\text { TUDOK” }\end{array}$} & \multicolumn{5}{|c|}{ az 1. helyen választott (fö) } & \multicolumn{3}{|c|}{$\begin{array}{l}\text { az 1., a } 2 \text {. és a } 3 \text {. } \\
\text { helyen választott }(\mathrm{db})\end{array}$} \\
\hline & $\begin{array}{l}\text { zene- } \\
\text { tanár }\end{array}$ & hittanár & $\begin{array}{r}\text { zene } \\
\text {-tanár és } \\
\text { hittanár } \\
\text { együtt } \\
\end{array}$ & $\begin{array}{l}\text { egyéb } \\
\text { tanár }\end{array}$ & össz & $\begin{array}{r}\text { zene } \\
\text {-tanár és } \\
\text { hittanár } \\
\text { együtt } \\
\end{array}$ & $\begin{array}{l}\text { egyéb } \\
\text { tanár }\end{array}$ & össz \\
\hline $\begin{array}{l}\text { Fontos a szakmai tudás és } \\
\text { tapasztalat }\end{array}$ & 26 & 28 & 54 & 32 & 86 & 54 & 22 & 76 \\
\hline $\begin{array}{l}\text { Nagy segítség a differenciált } \\
\text { óravezetés }\end{array}$ & 5 & 6 & 11 & 10 & 21 & 31 & 0 & 31 \\
\hline $\begin{array}{l}\text { Fontos az elfogadó légkör jó } \\
\text { példája }\end{array}$ & 14 & 18 & 32 & 18 & 50 & 74 & 30 & 104 \\
\hline $\begin{array}{l}\text { Szükséges a visszajelzés és a } \\
\text { fejlesztés (jutalom, játék) }\end{array}$ & 0 & 0 & 0 & 12 & 12 & 40 & 43 & 83 \\
\hline Fontos a személyiségfejlesztés & 3 & 0 & 3 & 14 & 17 & 49 & 40 & 89 \\
\hline $\begin{array}{l}\text { Egyre több a tanulási zavarral } \\
\text { küzdő tanuló }\end{array}$ & 0 & 0 & 0 & 14 & 14 & 8 & 28 & 36 \\
\hline $\begin{array}{l}\text { A gyermek az otthoni } \\
\text { problémákat az iskolába viszi }\end{array}$ & 0 & 0 & 0 & 0 & 0 & 7 & 17 & 24 \\
\hline & & & & Össze & $(\mathrm{db})$ & 263 & 180 & 443 \\
\hline
\end{tabular}

A hittanárok (52 fö) első választásai nagyon hasonló képet mutatnak. Csak három megállapítást adtak, amelyek közül legtöbben (28 fö) a szakmai tudást, 18 fó a jó és bizalommal teli légkört, míg hatan a differenciálás fontosságát hangsúlyozták. (6. táblázat). A véleményüket azzal indokolták, hogy a képzésük során kevés ismeretet kaptak a pedagógiai, pszichológiai módszerekről, aminek a hiányát érzik a tanítás során. Ezt azonban részben ellensúlyozhatják egy olyan légkör megteremtésével, ahol a gyerekek jó példát látnak, és érzik a szeretetet, a törődést. Ráadásul a tantárgyukból, a hivatásukból adódóan, úgy érzik, még elfogadóbbnak kell lenniük, és egy olyan attitüdöt kell közvetíteniük, ami könnyen követendő példa lehet minden tanítványuk számára. Ebben a modellteremtő feladatban is akadálynak érzik az életkori, a képességbeli és az ismeretbeli vegyes csoportokat, s ezért kezdik felismerni a differenciálás fontosságát. „Személyre szabott feladatot adok, hogy érezzék a fontosságukat, és hogy adottságaik képességé fejlödhessen ebben az elfogadó légkörben.”(hittanár, férfi, 33 éves). „A pedagógus, hittanár elöször önmagát fejlessze, 
képezze, majd felkarolja ezeket a gyerekeket és felzárkóztató programokkal, személyre szabott fejlesztő foglalkozásokkal segitse öket a fejlödésben. ”(hittanár, nő, 38 éves).

Az egyéb szakos tanárok választásai közül a legfontosabb a szakmai tudás és tapasztalat és a jó példát nyújtó légkör. Azonban a második vagy a harmadik helyen felsoroltak (személyiségfejlesztés; nő a tanulási zavarral küzdők száma; visszajelzés) nagyon hasonló arányban jeletek meg a válaszokban (12-14 fö). Nem csak megjegyzendő, de el is gondolkodtató, hogy a megkérdezett, a közismereti tárgyakat képviselö pedagógusok csak utolsó helyen említik meg a differenciált óravezetés fontosságát (10 fö, azaz csak minden tízedik személy). (6. táblázat)

Ha a teljes vizsgálati csoport (200 fó) adatait nézzük, amelyet úgy kaptunk, hogy együtt kezeltük az első - második - harmadik helyen leírt gondolatokat, akkor azt látjuk, hogy a hangsúlyok eltolódtak. Ugyan továbbra is fontos az elfogadó légkör (104 választás), mind a zenetanárok, a hittanárok és az egyéb tanárok esetében, de második legfontosabb a személyiségfejlesztés ( 89 választás), a harmadik pedig a diákok felé nyújtandó szükséges visszajelzések ( 83 választás). (6. táblázat)

Naponta hallani a gyerekekkel kapcsolatban álló szakemberektől, hogy a családok, a családi élet változásának a problémái, amelyeket a társadalmi változások indukálnak, megjelennek az iskolában is a tanulók teljesítményében és viselkedésében egyaránt. Ennek ellenére a teljes vizsgálati csoportban csak negyedik vagy későbbi állításként találkoztunk azzal, hogy a „gyermek az otthoni problémákat az iskolába viszi”. (6. táblázat)

Összefoglalóan megállapítható, hogy a vizsgálatban résztvevő személyek pedagógiai gyakorlatuk során legfontosabbnak tartják a szakmai tudást és a tapasztalatot. Fontos a jó példa, elfogadó légkör kialakítása, és a megfelelő személyiségfejlesztés, ezekhez szorosan kapcsolódik a differenciált óravezetés és a visszajelzés szükségessége.

\section{•, Amihez képeznem kell magamat ..."}

Arra kértük a vizsgálati személyeket, hogy gondolják végig eddigi pedagógiai gyakorlatukat aszerint, hogy hol szükséges a változtatás, milyen képzésben kellene részt venniük ahhoz, hogy eredményesen tudjanak foglalkozni az SNI tanulókkal. Válaszaikból a következő nyolc kategória rajzolódott ki:

1. Új pedagógiai, gyógypedagógiai módszerek, ismeretek elsajátítása

2. Tananyagtervezés, módszertan, fejlesztés, stb.

3. Alapvető pszichológiai, pedagógiai módszerek megismerése

4. Önfejlesztés

5. Technikai és multimédiás eszközök használata

6. Elmélet gyakorlatban való alkalmazása

7. Problémák felismerése

8. Sajátos nevelési igényü tanulók osztályszintủ integrálása

A zenetanárok és a hittanárok közül hasonlóan és egyforma arányban, közel minden második szakember érzi szükségességét annak, hogy többet tudjon a gyógypedagógia, a gyógypedagógiai módszerek témakörből (48 fő zenetanár és 52 fő hittanár közül 23-23 fö), illetve több ismerete legyen a tananyagtervezésröl és fejlesztésröl (17 és 14 fö). „Nem ártana a gyógypedagógiai szakmát is hozzátanulni a zenetanársághoz, hiszen a zenetanulás komoly terápiás eredménnyel is járhat. "(zenetanár, férfi, 38 éves) (7. táblázat)

A zenetanárok esetében ugyan mindig is volt tananyag, követelmény, de az adaptáció igénye nem merült fel, hiszen a zenetanulás bizonyos mértékig kiváltság volt, illetve a követelményeket valamilyen ok miatt teljesíteni nem tudó diákok egyszerűen, 
következmények nélkül nem folytatták a zenei tanulmányaikat. A tananyagfejlesztés igénye lassan kúszik be a zenei képzésbe.

A hittanárok a munkájukat csak az utóbbi években végzik tanóra szerint, órarendbe és iskolai környezetbe beágyazva. Számukra ez új helyzet, ami új kihívásokat hozott, például a hitismeret mint tananyag megjelenítése. Mára szükségessé vált, hogy a hitismereteket oktatók pedagógiai és pszichológiai ismeretekkel rendelkezzenek, ismerjék az oktatási folyamat elemeit, az életkori sajátosságokat, de miközben ezt tanulják, azonnal szembe kell nézniük az adaptáció szükségességével is. A hittanárok az alapképzésük során még hiányzó különféle pedagógiai módszereket, és egyéb technikákat szeretnének megismerni, pl. a differenciált óravezetést, az óratervek elkészítésének a módját, a tananyagtervezést, a szemléltető eszközök használatát, a motiválást, a fegyelmezést. De érzik azt is, hogy a hittanórák alkalmasak arra, hogy az SNI-s tanulók igényeit figyelembe vegyék, a személyiségüket és akár a tanuláshoz szükséges képességeiket is fejlesszék. „Képeznem kell magamat olyan módszer megismerésében, melyek a tanulási zavaros gyerekek könnyebb fejlesztésére, képességeik felszinre hozásában segitenek. ”(hittanár, nö, 26 éves).

Az egyéb szakos tanároknak több mint harmada a legnagyobb hiányt az önfejlesztésben érzi (100 főböl 38 fö) és a munkájukra vonatkozó gyógypedagógiai ismereteikben (24fö). (7. táblázat) A tananyagfejlesztés nem jelenik meg az első választások között körükben, ami csak a zenetanárok és a hittanárok oldaláról vizsgálva értelmezhető. Az alapképzésük során egyáltalán nem vagy kevés ismeretet szereztek az SNI tanulókkal kapcsolatos feladatok megoldására, a problémák felismerésére, a megfelelő módszerek kiválasztására, alkalmazására. Ebböl következik, hogy szeretnének még többet megtudni a tananyagtervezésröl, a módszertanról, a fejlesztésröl, mert úgy érzik, ezek ismeretében hatékonyabban tudnának foglalkozni az SNI tanulókkal.

7.táblázat A vizsgálati személyek szakja és ,amihez képezni kell magamat” (forrás: a szerzö)

\begin{tabular}{|c|c|c|c|c|c|c|c|c|}
\hline \multirow[b]{2}{*}{$\begin{array}{c}\text { „AMIHEZ } \\
\text { KÉPEZNEM KELL } \\
\text { MAGAMAT” }\end{array}$} & \multicolumn{5}{|c|}{ az 1. helyen választott (fö) } & \multicolumn{3}{|c|}{\begin{tabular}{|c|} 
az 1., a 2. és a 3. \\
helyen választott $(\mathrm{db})$
\end{tabular}} \\
\hline & $\begin{array}{l}\text { zene- } \\
\text { tanár }\end{array}$ & hittanár & $\begin{array}{r}\text { zene } \\
\text {-tanár és } \\
\text { hittanár } \\
\text { együtt }\end{array}$ & $\begin{array}{l}\text { egyéb } \\
\text { tanár }\end{array}$ & össz & $\begin{array}{r}\text { zene } \\
\text {-tanár és } \\
\text { hittanár } \\
\text { együtt }\end{array}$ & $\begin{array}{c}\text { egyéb } \\
\text { tanár }\end{array}$ & össz \\
\hline $\begin{array}{l}\text { Új ped., gyógyped. módszerek, } \\
\text { ismeretek }\end{array}$ & 23 & 23 & 46 & 24 & 70 & 46 & 51 & 97 \\
\hline $\begin{array}{l}\text { Tananyagtervezés és fejlesztés, } \\
\text { módszertan }\end{array}$ & 17 & 14 & 31 & 0 & 31 & 54 & 21 & 75 \\
\hline $\begin{array}{l}\text { Alapvető pszichológiai, } \\
\text { pedagógiai módszerek }\end{array}$ & 2 & 7 & 9 & 10 & 19 & 28 & 22 & 50 \\
\hline Önfejlesztés & 4 & 8 & 12 & 38 & 50 & 44 & 72 & 116 \\
\hline $\begin{array}{l}\text { Technikai és multimédiás } \\
\text { eszközök használata }\end{array}$ & 2 & 0 & 2 & 6 & 8 & 28 & 11 & 39 \\
\hline $\begin{array}{l}\text { Elmélet gyakorlatban való } \\
\text { alkalmazása }\end{array}$ & 0 & 0 & 0 & 6 & 6 & 27 & 23 & 50 \\
\hline Problémák felismerése & 0 & 0 & 0 & 12 & 12 & 13 & 25 & 38 \\
\hline $\begin{array}{l}\text { Tanulási nehézségekkel } \\
\text { küzdők integrálása }\end{array}$ & 0 & 0 & 0 & 4 & 4 & 0 & 12 & 12 \\
\hline & & & & Sszzesíte & $(\mathrm{db})$ & 240 & 237 & 477 \\
\hline
\end{tabular}

A vizsgálati személyek által írt magyarázatok jól mutatják, hogy a pedagógusok fontosnak tartják a folyamatos szakmai képzést. A számukra új ismeretet nyújtó továbbképzéseken szívesen vennének részt, de nem teheti meg mindenki a földrajzi távolság, a költségei miatt, 
vagy mert az iskola vezetősége nem járul hozzá a távolléthez. Alternatívaként alkalmazzák a pedagógusok az önfejlesztést, szakkönyveket olvasnak, az interneten böngésznek, elsősorban az egyéb szakosok. A módszer előnye mellett (beoszthatja az idejét, otthon végezheti, csak azzal foglalkozik, ami valóban érdekli) azonban vannak hátrányai, sőt veszélyei is, ha az internet káoszára, ellenőrizetlenségére gondolunk, hiszen könnyü elkalandozni, nehéz eldönteni, mi a fontos és mi a téves információ stb., de azért is, mert gyakran közbe jöhet valami, erös önfegyelem stb. szükséges a következetes önfejlesztéshez.

„A tanitás tulajdonképpen egy folyamatos tanulás. Egy jó pedagógus mindig arra törekszik, hogy ismereteit szélesitse, képezze magát.”(zenetanár, nő, 53 éves). „Jól bevált módszereket szeretnék tanulni, olyanokat, amiket mások már sikerrel alkalmaztak pedagógiai munkájuk során. "(hittanár, férfi, 42 éves) Világosan látható, hogy a pedagógusok érzik a továbbképzés fontosságát és igényük is van rá, történjen az szervezett keretek között vagy önképzés formájában. Az elméleti ismeretek mellett igény van arra, hogy azokat gyakorlatban is tudják hasznosítani, olyan módszereket, technikákat szeretnének megismerni, amelyeket a mindennapi tanításuk során tudnak hasznosítani.

\section{- „Amiben segitségre van szükségem az oktatási adaptáció során .....”}

A vizsgálatban részt vevő zenetanárok és hittanárok többsége már találkozott a pedagógusként sajátos nevelési igényü gyerekkel. A zenetanárok munkájukban egyénileg foglalkoznak a növendékekkel, így a személyre szabott, egyéni bánásmód is jobban érvényesülhet. A hittanárok már több nehézséget tapasztalnak az együttnevelés területén, mondván nincs megfelelő pedagógiai felkészültségük, alkalmazható tanulási programjuk, ráadásul a tárgyi és a személyi feltételek sem adottak mindenhol. Arra a kérdésére, hogy milyen segítségre van szükségük az oktatási adaptáció során, az igények 7 kategóriába voltak besorolhatóak:

1. Szakmai és szociális együttmúködés

2. Szakmai tanács tapasztalt kollégáktól

3. Legyen pedagógiai asszisztens a tanórán

4. Támogatás: pénzbeli, időbeli és szülöi

5. Továbbképzések: integrációs programok, alkalmazott módszerek

6. Támogatás: vezetôség, kollégák, más szakemberek

7. Megfelelő oktatási környezet a fejlesztéshez

A szakmai és a szociális támogatás, valamint a tapasztalattal rendelkező kollégák tanácsai, bár fordított sorrendben, de az első választásként megnevezett igények első két helyén szerepelt. A zenetanároknak közel fele inkább az együttmüködésből (28 fó), a hittanároknak pedig több mint a fele (30 fó) a tapasztalt kollégák gyakorlati tanácsaiból szeretne többet. (8. táblázat) „Tapasztalt kollégával vagy közismereti tanárral konzultálni egy-egy problémás gyerekröl."(hittanár, férfi, 39 éves). A magyarázatokban azt emelték ki, hogy nehezíti a munkájukat, hogy nincs megfelelö kommunikáció a gyerekek nevelöi között, ezért kevés és hiányos információ jut el hozzájuk. Ritkán találkoznak olyan szakemberekkel, akik hatékonyan tudnának segíteni a saját szakmai fejlődésükben vagy a tanítványaikkal kapcsolatban. Segítség lenne, ha mások gyakorlatát jobban megismerhetnék, hospitálhatnának tapasztaltabb kollégák óráin, és fontos lenne számukra, ha alkalom nyílna közös munkára és megbeszélésre a fejlesztőpedagógussal, a gyógypedagógussal, más szaktanárral és a pszichológussal.

Ha csak az arányokat nézzük, akkor az egyéb szakosok jellemzően (58 fö), a zenetanárokhoz hasonlóan a különbözö tartalmú közös munkát hiányolja a mindennapok gyakorlatából. (8. táblázat) 
A 200 fős vizsgálati csoport a legnagyobb szükségét, az első - második - harmadik helyen megjelölt választásoknak az összesítése alapján a szakmai és a szociális együttmüködésnek $(114 \mathrm{db})$ és a témát érintő (SNI tanulók integrációja, módszerek) továbbképzéseknek érzik. Meglepő, hogy a tanórai munkát segítő pedagógiai asszisztensek jelenlétét szinte egyáltalán nem igénylik ( 5 fö) a megkérdezett vizsgálati személyek. A zenetanárok azok, akik, ha kevés esetben is (11 db választás), de jobb, megfelelőbb oktatási környezetet szeretnének, hogy a munkájuk eredményesebb lehessen. (8. táblázat) Elmondásuk szerint gyakran elöfordul, hogy az óráikat olyan termekben kell megtartaniuk, amelyek nem alkalmasak erre a célra. Rajzteremben, technikateremben, müvelődési házak ablaktalan, sötét, szük termeiben nem tudnak hatékonyan dolgozni, ahol nem meglepö módon a megfelelő eszközök sem állnak a rendelkezésükre (pl. kottatartó állványok, húrok, gyanták, fénymásolási lehetőségek).

8. táblázat A vizsgálati személyek szakja és ,,amiben segitségre van szükségem...” (forrás: a szerzö)

\begin{tabular}{|c|c|c|c|c|c|c|c|c|}
\hline \multirow[b]{2}{*}{ „SZÜKSÉGEM VAN... , } & \multicolumn{5}{|c|}{ az 1. helyen választott (fó) } & \multicolumn{3}{|c|}{$\begin{array}{c}\text { az 1., a 2. és a } 3 . \\
\text { helyen választott }(\mathrm{db})\end{array}$} \\
\hline & $\begin{array}{l}\text { zene- } \\
\text { tanár }\end{array}$ & hittanár & $\begin{array}{r}\text { zene- } \\
\text { tanár és } \\
\text { hittanár } \\
\text { együtt }\end{array}$ & $\begin{array}{l}\text { egyéb } \\
\text { tanár }\end{array}$ & össz & $\begin{array}{l}\text { zene- } \\
\text { tanár és } \\
\text { hittanár }\end{array}$ & $\begin{array}{l}\text { egyéb } \\
\text { tanár }\end{array}$ & össz \\
\hline $\begin{array}{l}\text { Szakmai, mentális, szociális } \\
\text { együttmüködés, segítség }\end{array}$ & 28 & 16 & 44 & 58 & 102 & 44 & 70 & 114 \\
\hline $\begin{array}{l}\text { Szakmai tanács tapasztalt } \\
\text { kollégáktól }\end{array}$ & 11 & 30 & 41 & 9 & 50 & 57 & 25 & 82 \\
\hline $\begin{array}{l}\text { Pedagógiai asszisztens } \\
\text { tanórán }\end{array}$ & 2 & 0 & 2 & 3 & 5 & 2 & 3 & 5 \\
\hline $\begin{array}{l}\text { Pénzbeli, időbeli ráfordítás, } \\
\text { szülői támogatás }\end{array}$ & 7 & 4 & 11 & 11 & 22 & 55 & 20 & 75 \\
\hline $\begin{array}{l}\text { Integrációs programok, } \\
\text { továbbképzés a témában }\end{array}$ & 0 & 0 & 0 & 4 & 4 & 20 & 27 & 47 \\
\hline $\begin{array}{l}\text { Vezetőség, szakemberek, } \\
\text { kollégák támogatása }\end{array}$ & 0 & 2 & 2 & 7 & 9 & 41 & 17 & 58 \\
\hline $\begin{array}{l}\text { Megfelelö környezet } \\
\text { kialakítása a fejlesztéshez }\end{array}$ & & & & & & 11 & 2 & 13 \\
\hline $\begin{array}{ll}\text { Pedagógusok } & \text { lelki } \\
\text { támogatása } & \end{array}$ & & & & & & 6 & 18 & 24 \\
\hline $\begin{array}{l}\text { Alkalmazott pedagógiai } \\
\text { módszerekről tanulás }\end{array}$ & 0 & 0 & 0 & 8 & 8 & 34 & 22 & 56 \\
\hline & & & & Össze & $(\mathrm{db})$ & 270 & 204 & 474 \\
\hline
\end{tabular}

A vizsgálatban részt vevő pedagógusok igénylik és kérik a különböző szakmai, mentális, szociális szakemberek segítségét, akik olyan pszichológiai, pedagógiai módszerekkel, integrációs programokkal, fejlesztő játékokkal ismertetik meg őket, amelyek segítségével hatékonyon tudnak foglalkozni az SNI gyerekekkel. A továbbképzéseken való részvétel biztosításához szükséges a vezetőség támogatása, a kollégák nyitottsága pedig az új módszerek megismerésére, alkalmazására.

\section{Következtetések}

Társadalmi elvárás és minden pedagógus érdeke, hogy javuljon az oktatás minősége, melynek középpontjában a gyerek fejlődése áll. Az eredmények eléréséhez elengedhetetlen a személyre szabott, egyéni képességeket figyelembe vevő fejlesztés. A sajátos nevelési igényü gyerekekkel való foglalkozás során, a vizsgálati személyek szerint, akik esetünkben a munkájuk során találkoznak velük, több akadályozó tényezőt is felsoroltak, amelyek nehezítik 
az eredményes munkát. A gyerekek családi háttere, a szülöi érdektelenség, a gyerekek közötti nagy különbségek, a pénz-, idő- és eszközhiány ugyanúgy akadályként állnak a hatékony fejlesztés útjában, mint az, ha nincs megfelelő ismerete a pedagógusnak a tanulási zavarokról, a viselkedési problémákról, az SNI-ről, amit csak tovább fokoz a túlterheltség is.

A jelen vizsgálat adataiból, amely nem volt reprezentatív és a feldolgozása leíró statisztikai módszerrel történt, kitünik, hogy a pedagógusok jól látják hiányosságaikat és nyitottak a változtatásra, s ennek érdekében szorosabb kapcsolatot tartanak a szülőkkel, szakemberekkel. Nagy hangsúlyt fektetnek az új módszerek elsajátítására és a személyes kapcsolat kialakítására a tanulóval, amihez alap a már meglévő szakmai tudás, tapasztalat, a differenciált óravezetés, a jó példa és az elfogadó légkör. Ezekre a meglévő ismeretekre lehet alapozni az új pedagógiai, gyógypedagógiai, pszichológiai módszerek ismeretének az elsajátítását, a tananyagtervezés, módszertan, fejlesztések megismerését. Hasznos információkat, biztos szakmai és módszertani tudást, jó gyakorlatokat szerezhetnek a továbbképzéseken, melyek segítik az elméletet a gyakorlatban alkalmazni.

$\mathrm{Az}$ eredményes munkához szükségesnek tartják a szakmai, mentális, szociális együttmüködést és segítségnyújtást, a szülöi támogatást, illetve a pénz-, idő-, eszköztámogatást, a vezetőség, a kollégák támogatását, tapasztalt kollégák szakmai segítségét, a megfelelő oktatási környezet kialakítását a fejlesztéshez, az integrációs programok megismerését, továbbképzéseken való részvétel biztosítását.

A vizsgálati eredmények alapján elmondható, hogy a pedagógusok nagy többsége valójában kevés információval és gyakorlattal rendelkeznek az SNI gyerekek oktatásával kapcsolatosan, de ha megfelelő segítséget és támogatást kapnak, akkor nyitottak az inkluzív nevelés felé.

\section{IRODALOM}

Csébfalvi, É. (1998). MUSE-E A zene, mint az egyensúly és tolerancia forrása, Magyar Alkotómüvészeti Közalapítvány, Budapest.

Dohány, G. (2009). Zenei élmény az énekórán? Iskolakultúra, 3, 70-79.

Hernádi, K. (2008). A pedagógus In. Kőpatakiné Mészáros Mária. Útravaló pedagógusoknak az intézményi implementációs folyamatok gyakorlattá válásához. Educatio, 25-31.o.

Janurik, M. (2008). A zenei képességek szerepe az olvasás elsajátításában. Magyar Pedagógia 108. évf. 4. szám 289-317.

Palatin, K. (2015). A zenetanulás nehézségei tanulási zavarral küzdő gyermekeknél (Letöltés. 2017. 03. 18.). (Web: http.//www.parlando.hu/2015/2015-6/Palatin_Krisztina.htm).

Reikort, I. (2009). Zenevarázs, Educatio Társadalmi Szolgáltató Nonprofit Kft.Budapest (Letöltés. 2017.03.

18.).

(Web: http.//www.sulinet.hu/tanar/kompetenciateruletek/ovodai_neveles/dokumentumok/zenevar azs.pdf).

Réthy, E. (2013). Befogadás, méltányosság, az inkluzív pedagógia rendszere. Comemius Oktató és Kiadó Kft., Pécs 137-155.

Net1. A hitoktató feladatai és kapcsolatai. (Letöltés: 2017. 05.01.). (Web: http://szolgalohittan.hu/+!DeoGratias/+DG.Kiado/PPKE-BTK/2.4.H-feladatai.pdf).

Net2. A hitoktató személye, felkészültsége - képzése. (Letöltés: 2017. 05.01.). (Web: http://szolgalohittan.hu/+!DeoGratias/+DG.Kiado/PPKE-BTK/2.3.H-szemelye.pdf).

Net3. 2017-től már csak 5 éves osztatlan képzés indul. (Letöltés: 2017. 05.01.). (Web: http://www.dnyem.hu/index.php/item/805-2017-tol-mar-csak-5-eves-osztatlan-kepzesindul).

Net 4. 8/2013. (I. 30.) EMMI rendelet a tanári felkészítés közös követelményeiről és az egyes tanárszakok képzési és kimeneti követelményeiről. (Letöltés: 2017. 05.01.). (Web: https://net.jogtar.hu/jr/gen/hjegy_doc.cgi?docid=a1300008.emm). 